\title{
DAMPAK KEMAJUAN TEKNOLOGI INFORMASI TERHADAP BIDANG AKUNTANSI MANAJEMEN
}

\author{
Meldona \\ Jurusan Akuntansi Fakultas Ekonomi \\ Universitas Islam Negeri (UIN) Maulana Malik Ibrahim Malang \\ Email: meldona_nurlatifa@yahoo.co.uk
}

\begin{abstract}
Information technology development has significantly changed the businesses. Various kinds of information systems which use information technology are Electronic Data Processing Systems (EDP), Data Processing Systems (DPS), Decision Support System (DSS), Management Information System (MIS), Executive Information Systems (EIS), Expert System (ES) and Accounting Information System (AIS). The development of information technology has also influenced management accounting dicipline as the producer of information for planning, controling and decision making. These influences, of course, has advantages and diadvantages for the companies.
\end{abstract}

Keywords: information technology, management accounting, decision making.

Perkembangan teknologi informasi (TI) yang begitu pesat membawa pengaruh yang luas terhadap peradaban umat manusia saat ini khususnya dalam dunia usaha, dengan jarak yang semakin dekat dan kebutuhan informasi yang semakin cepat, maka mau tidak mau suka tidak suka kompetensi diri harus dikembangkan untuk dapat mengikuti trend teknologi informasi yang ada.

Trend TI dalam dunia bisnis/usaha saat ini mempengaruhi bukan saja terhadap pengolahan data source (sumber data) yang berupa data transaksi, dengan tujuan untuk memberikan kemudahan dalam menghasilkan informasi yang dapat dipercaya, relevan, tepat waktu, lengkap, dapat dipahami, dan teruji (Maharsi, 2001). Lebih lanjut pemrosesan informasi tersebut juga berpengaruh terhadap pola kegiatan industri dengan penggunaan software yang dapat meningkatkan otomatisasi pabrik (Supriyono, 1997). Hal tersebut berpengaruh terhadap kebijakan pengoperasian untuk meminimumkan persediaan yang 
mempunyai dampak pada praktik-praktik akuntansi, khususnya akuntansi manajemen.

Akuntansi manajemen digunakan untuk mengukur kinerja manajemen, sehingga akuntansi manajemen perlu memperhatikan aspek perilaku manusia dalam organisasi dalam pengolahan informasi keuangan (Mulyadi, 1993: 7). Lebih lanjut, Hansen \& Mowen (2000) menyebutkan bahwa akuntansi manajemen merupakan salah satu dari cabang akuntansi yang menyangkut rekayasa sistem informasi untuk memenuhi kebutuhan intern manajemen, informasi keuangan intern tersebut diperlukan para manajer untuk mendukung pengambilan keputusan dalam rangka pengelolaan dan pengendalian organisasi bisnis, dengan perkataan lain, akuntansi manajemen menghasilkan informasi bagi para manajer. Manajer di era informasi akan lebih banyak membutuhkan informasi untuk pengambilan keputusan dalam rangka meraih peluang untuk kepentingan eksternal dan mencapai tujuan yang optimal demi kepentingan internal.

Berbagai penelitian telah banyak dilakukan mengenai keterkaitan teknologi informasi dengan akuntansi seperti Noviera (2000), yang membahas tentang pengaruh kemajuan teknologi informasi terhadap perkembangan akuntansi. Juga Maharsi (2001) yang mengulas tentang pengaruh perkembangan teknologi informasi di bidang akuntansi manajemen. Empiris lain yang mengkaji tentang implementasi teknologi informasi berpengaruh terhadap produktivitas di perusahaan manufaktur (Ellitan, 2004) yang mengemukakan bahwa teknologi berperan penting dalam meningkatkan kinerja operasional seperti kecepatan waktu proses produksi, penurunan produk cacat, kemampuan penghantaran tepat waktu dan peningkatan produktivitas.

Studi ini merupakan kelanjutan dari studi yang dilakukan oleh Maharsi (2001), yang membahas tentang pengaruh perkembangan teknologi informasi di bidang akuntansi manajemen. Namun dalam penelitian ini ditambah dengan kajian tentang implementasi teknologi informasi yang dikaitkan pula dengan karakteristik sistem informasi akuntansi. Karena keberhasilan implementasi teknologi informasi akan dipengaruhi oleh kepiawaian manajemen dalam 
menyikapi karakteristik sistem informasi akuntansi yang berpengaruh dalam setiap keputusan manajemen yang diambil.

\section{TEKNOLOGI INFORMASI}

Teknologi informasi muncul sebagai akibat semakin merebaknya globalisasi dalam kehidupan organisasi, semakin kerasnya persaingan bisnis, semakin singkatnya siklus hidup barang dan jasa yang ditawarkan, serta meningkatnya tuntutan selera konsumen terhadap produk dan jasa yang ditawarkan. Untuk mengantisipasi semua ini, perusahaan mencari terobosan baru dengan memanfaatkan teknologi. Teknologi diharapkan dapat menjadi fasilitator dan interpreter. Semula teknologi informasi digunakan hanya terbatas pada pemrosesan data. Dengan semakin berkembangnya teknologi informasi tersebut, hampir semua aktivitas organisasi saat ini telah dimasuki oleh aplikasi dan otomatisasi teknologi informasi.

Teknologi informasi merupakan salah satu alat manajer untuk mengatasi perubahan (Laudon dan Laudon, 2006: 14). Definisi TI secara lengkap dinyatakan oleh Martin et al. (2002: 1), yaitu teknologi komputer yang digunakan untuk memproses dan menyimpan informasi serta teknologi komunikasi yang digunakan untuk mengirimkan informasi. Definisi TI sangatlah luas dan mencakup semua bentuk teknologi yang digunakan dalam menangkap, manipulasi, mengkomunikasikan, menyajikan, dan menggunakan data yang akan diubah menjadi informasi (Martin et al., 2002: 125).

Lingkungan teknologi memungkinkan perusahaan untuk memajukan kinerjanya. TI dan kinerja memiliki hubungan simbiosis. Perkembangan TI yang terjadi selama ini mencakup perkembangan infrastruktur TI, yakni hardware, software, data, dan komunikasi (McNurlin dan Sprague, 2002: 11). Menurut Laudon dan Laudon (2006: 14-15), infrastruktur TI terdiri atas komponen hardware, software, teknologi penyimpanan data (storage), serta teknologi komunikasi. Beberapa penulis mengklasifikasikan teknologi storage ke dalam 
komponen hardware sehingga komponen TI terdiri atas hardware, software, dan komunikasi (McLeod dan Schell, 2004: 101-123; Mescon et al., 2002: 213 - 219).

\section{PERAN TEKNOLOGI INFORMASI}

Industrialisasi membawa teknologi baru dalam kegiatan manufaktur karena semakin banyak bahan baku yang dapat diolah menjadi produk, dan dengan adanya tambahan enerji maka kapasitas tenaga manusia dapat dilipat gandakan, sehingga berdampak pada cara hidup dan pola berfikir dalam masyarakat, akibatnya semakin banyak tersedia produk yang khusus memberikan pemenuhan kebutuhan tertentu (specialized).

Industrialisasi bersama teknologi yang ada menyebabkan terjadi perubahan yang sangat mendasar pada aspek sosial dan ekonomi, penciptaan kemakmuran masyarakat menganut faham efisiensi melalui operasi skala besar (mass production) yang dilaksanakan melalui proses industri Disekitar tahun 50an ditemukan semi konduktor pada teknologi komputer yang menandai dimulainya era informasi, sehingga faktor yang mendorong pertumbuhan sistem sosial dan ekonomi bukan lagi tenaga kerja maupun tenaga mesin melainkan informasi, bagi yang menguasai dan memanfaatkan informasi itulah yang akan berhasil, sebagaimana yang disampaikan oleh Alfin Toffler: “Barangsiapa yang ingin menguasai era globalisasi maka kuasai informasi".

Negara yang mampu berkompetisi karena memiliki kekuatan ekonomi yang besar adalah yang mampu memanfaatkan knowledge workers secara efektif, dengan menguasai dan memanfaatkan informasi maka paradigma penciptaan kemakmuran secara dominan dapat diwujudkan, dan pada era ini TI lebih banyak didukung oleh peran dari teknologi komputer digital dan teknologi komunikasi. 


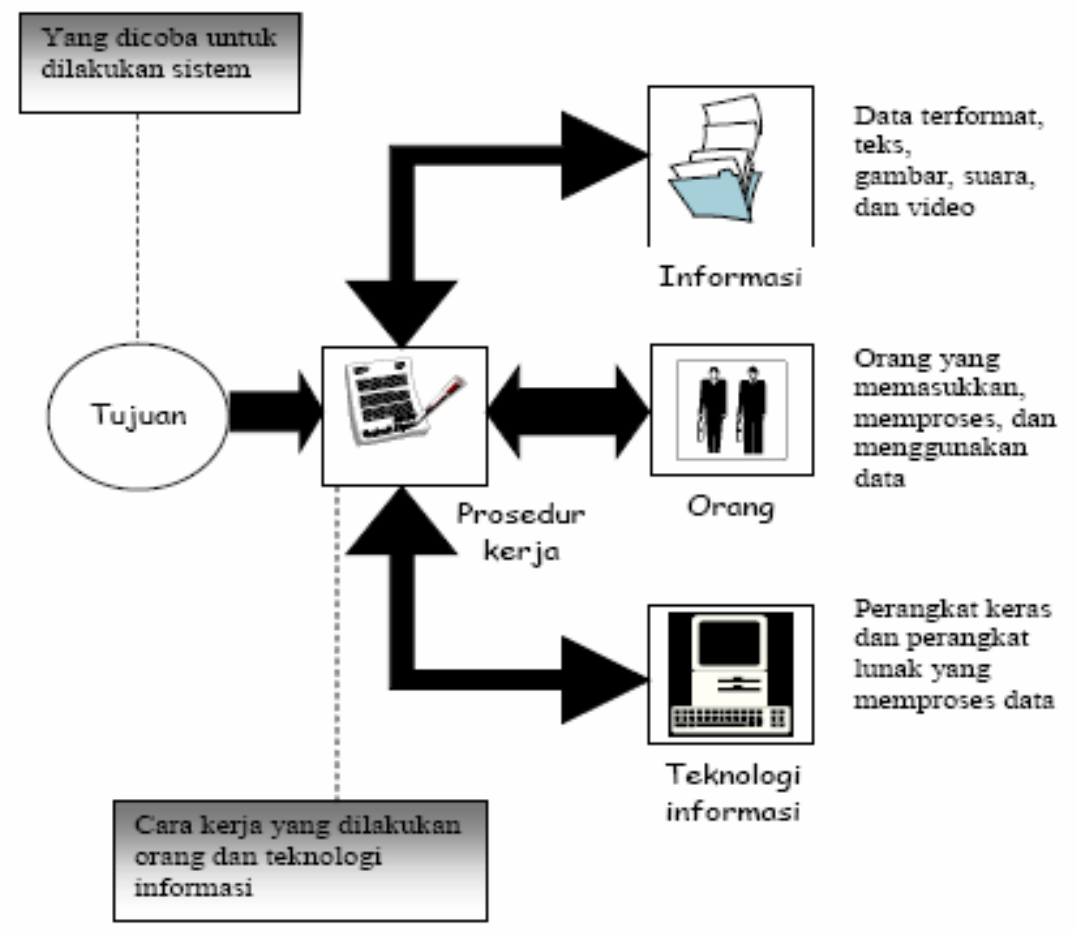

Gambar 1. Komponen Sistem Teknologi Informasi

\section{PERKEMBANGAN TEKNOLOGI INFORMASI}

Teknologi Informasi (TI) meliputi segala alat maupun metode yang terintegrasi untuk digunakan dalam menjaring atau menangkap data (capture), menyimpan (saving), mengolah (process), mengirim (distribute), atau menyajikan kebutuhan informasi secara elektronik kedalam berbagai format, yang bermanfaat bagi user (pemakai informasi). Teknologi ini dapat berupa kombinasi perangkat keras dan lunak dari komputer, non komputer (manual) maupun prosedur, operator, dan para manajer dalam suatu sistem yang terpadu satu sama lain.

Perkembangan TI telah mengakibatkan perubahan dalam struktur industri serta praktik pengelolaan organisasi bisnis di dalam berkompetisi dan melaksanakan kegiatan untuk melayani pelanggan, sehingga dengan laju perkembangan TI yang semakin pesat telah mengubah bisnis dan konsep manajemen yang ada, juga berdampak terhadap kebutuhan informasi bagi manajer dalam akuntansi internal maupun eksternal guna mendukung dalam pemecahan masalah untuk pengambilan keputusan, meraih peluang dan 
mencapai tujuan. Teknologi informasi dipakai dalam sistem informasi organisasi untuk menyediakan informasi bagi para pemakai dalam rangka pengambilan keputusan.

Ada berbagai macam sistem informasi dengan menggunakan teknologi informasi yang muncul, antara lain Electronic Data Processing Systems (EDP), Management Information System (MIS), Decision Support System (DSS), Expert System (ES), Data Processing Systems (DPS), Executive Information Systems (EIS), dan Accounting Information System (AIS) (Bodnar, 1998). Saluran komunikasi yang dapat digunakan untuk berkomunikasi adalah standard telephone lines, coaxial cable, fiber optics, microwave systems, communications satellites, cellular radio and telephone. Sedangkan konfigurasi jaringan yang dapat dipakai untuk berkomunikasi adalah Wide Area Network (WAN), Local Area Network (LAN), dan Client/Server Configurations (Romney, 2000).

Electronic Data Processing Systems (EDP) adalah penggunaan teknologi komputer untuk menyelenggarakan pemrosesan data yang berorientasi pada transaksi organisasi. Sistem ini digunakan untuk mengolah data transaksi yang sifatnya rutin (sehari-hari). Sistem ini tidak dapat membantu pekerjaan pihak manajemen yang berkaitan dengan pengambilan keputusan. Sistem ini hanya bermanfaat untuk meningkatkan ketepatan waktu dan frekuensi penyajian laporan. Secara fundamental, EDP merupakan aplikasi sistem informasi akuntansi dalam setiap organisasi. Istilah data processing (DP) sebenarnya sama dengan EDP.

Management Information System (MIS), merupakan penggunaan teknologi komputer untuk menyediakan informasi yang berorientasi pada manajemen level menengah. MIS mengakui adanya kenyataan bahwa para manajer dalam suatu organisasi membutuhkan informasi dalam rangka pengambilan keputusan dan bahwa sistem informasi berbasis komputer dapat membantu penyediaan informasi bagi para manajer.

Decision Support System (DSS), adalah suatu sistem informasi yang datanya diproses dalam bentuk pembuatan keputusan bagi pemakai akhir. Karena berorientasi pada pemakai akhir, maka DSS membutuhkan penggunaan 
model-model keputusan dan database khusus yang berbeda dengan sistem DP. DSS diarahkan pada penyediaan data yang nyata, khusus, dan informasi yang tidak rutin yang diminta oleh manajemen. DSS dapat digunakan untuk menganalisis kondisi pasar sekarang atau pasar potensial. DSS juga dapat membantu mengubah proses bisnis, dimana umumnya manajer membuat semua keputusan, namun dengan adanya teknologi informasi seperti decision support tools, access database, dan modelling software, pengambilan keputusan menjadi bagian setiap orang.

Expert System (ES), merupakan sistem informasi yang berbasis pada pengetahuan yang menggunakan pengetahuan tentang bidang aplikasi khusus untuk menjalankan kegiatan sebagai konsultan ahli bagi pemakai akhir. Seperti DSS, ES membutuhkan penggunaan model-model keputusan manajemen dan database khusus. Tidak seperti DSS, ES juga membutuhkan pengembangan basis pengetahuan dan inference engine. Jika DSS membantu manajemen dalam rangka pengambilan keputusan, maka ES membuat keputusan tersebut.

Executive Information Systems (EIS), merupakan suatu sistem informasi yang berkaitan dengan kebutuhan manajemen puncak mengenai informasi strategik dalam proses pengambilan keputusan strategik. Sedangkan AIS merupakan sebuah sistem yang menyediakan informasi bersifat keuangan dan non keuangan bagi para pengambil keputusan.

Penggunaan teknologi informasi pada aktivitas perusahaan seperti pada value chain dapat menghasilkan beberapa keuntungan, seperti penghematan biaya, percepatan waktu operasi, peningkatan produktivitas, percepatan waktu pengiriman barang dan jasa kepada pelanggan, serta peningkatan nilai barang dan jasa yang tinggi pada pelanggan.

Salah satu teknologi informasi yang tidak kalah pentingnya adalah pemakaian Electronic Data Interchange (EDI). EDI adalah komunikasi antar komputer dengan tujuan meningkatkan efektivitas dan mengurangi pekerjaan yang sifatnya klerikal. Hansen dan Hill (1989) mendefinisikan EDI sebagai pergerakan dokumen bisnis dalam format terstruktur antara berbagai patner bisnis dalam suatu organisasi. Dengan EDI, dokumen yang diterima dapat 
memerintahkan komputer secara otomatis. EDI yang terintegrasi memberikan peluang pada manajer untuk berkonsentrasi penuh pada pengambilan keputusan strategik dan meningkatkan kemampuan dalam pengendalian beberapa aktivitas. Teknologi dengan kemajuan global akan terus berkembang. Sementara itu, teknologi informasi yang kuat akan menjadi competitive edge bagi perusahaan dan sekaligus menjadi entry barrier (Fasio, 1994). Bagi organisasi yang ingin maju dan berkembang, tidak ada alasan untuk tidak menggunakan teknologi sepanjang hal itu dapat mempermudah perusahaan menyesuaikan diri dengan lingkungannya (Hanscombe, 1989).

\section{DAMPAK KEMAJUAN TEKNOLOGI INFORMASI TERHADAP BIDANG AKUNTANSI MANAJEMEN}

Sebagaimana diketahui bahwa bidang akuntansi dibagi atas tiga subbidang yaitu akuntansi manajemen, akuntansi keuangan, dan auditing maka akibat perkembangan TI akan berpengaruh terhadap bisnis dan praktik manajemennya yang meliputi akuntansi keuangan dan akuntansi manajemen demikian juga terhadap proses auditing, sehingga Auditor yang berkembang di era informasi ini adalah yang mampu memberikan jasa tebaik bagi klien dengan memanfaatkan TI

Perkembangan TI mengakibatkan accountability technology (teknologi pertanggungjawaban) perusahaan juga mengalami perkembangan, dari teknik single entry bookkeeping yaitu model laporan keuangan neraca yang menunjukkan kemamuran saat tertentu (p) kemudian ke teknik double entry bookkeeping berupa laporan laba-rugi dan laporan perubahan posisi keuangan (modal) sebagai cerminan kemakmuran pada periode tertentu $\left(\mathrm{p}^{\prime}\right)$, pada saat ini di era informasi diajukan teknik triple entry bookkeeping yang dikemukakan oleh Yuji Ijiri, disamping masih didasarkan pada laporan neraca, laba-rugi, dan perubahan posisi keuangan juga diharapkan teknik ini mampu menunjukan laporan perubahan laba dalam jangka waktu tertentu $\left(\mathrm{p}^{\prime \prime}\right)$. 
Akuntansi manajemen merupakan cabang akuntansi yang menyangkut rekayasa sistem informasi untuk memenuhi kebutuhan intern manajemen, informasi keuangan intern tersebut diperlukan para manajer untuk mendukung pengambilan keputusan dalam rangka pengelolaan dan pengendalian organisasi bisnis, dengan perkataan lain, akuntansi manajemen menghasilkan informasi bagi para manajer. Organisasi dalam era informasi didukung oleh personalia yang sebagian besar tergolong sebagai knowledge workers, dengan demikian, akuntansi manajemen pada era informasi sebaiknya tidak hanya melayani kebutuhan manajer saja, tetapi juga para perkerjaan yang lain, karyawan yang melaksanakan kegiatan operasional memerlukan informasi untuk pengendalian kegiatan Informasi yang diukur dan disajikan dalam laporan keuangan pada dasarnya mengikuti pola kebutuhan inforasi pada era industri level $p$, dan $\mathrm{p}^{\prime}$ berupa aktiva, kewajiban, pendapatan, biaya dan laba, sehingga sistem akuntansi pun dirancang untuk menghasilkan informasi tersebut.

Assets yang dicatat dan dilaporkan pada sebagaian besar adalah asset yang tangible (berwujud) yang sesuai dengan era industri, dalam neraca dapat dilihat unsure assetnya terdiri atas penyediaan, aktiva tetap yang berupa mesin mesin, gedung dan peralatan, asset tersebut dicatat dengan dasar cost jadi lebih banyak dilihat dari sisi produksi bukan dari sisi nilainya yang mungkinlebih cocok menurut pandangan konsumen.

Prinsip pengakuan dalam akuntansi pada umumnya menggunakan terjadinya transaksi dengan pihak luar perusahaan, tanpa ada transaksi maka tak akan ada pencatatan (pendokumentasian), jadi akuntansi hanya mencatat dan melaporkan segala sesuatu atas dasar kejadian yang terjadi pada masa lalu, struktur kode perkiraan dalam sistem akuntansi pada era industri biasanya dirancang dengan acuan struktur organisasi yang hierarkhis, sementara struktur kode tipikal pada umumnya mengikuti pola "semakin rinci sesuatu maka semakin kea rah kanan kodenya". Struktur hierarkhis ini sangat memudahkan proses penyusunan laporan menurut tingkat organisasi dari yang terendah sampai yang tertinggi, sebenarnya pola struktur ini memaksakan pola organisasi fungsional hierarkhis yang tidak sesuai dengan organisasi jaringan pada era 
informasi, sementara data anggaran dan biaya terpaksa harus dicatat mengikuti struktur kode yang ada, sehingga tidak mungkin dilakukan penanganan secara efektif biaya yang sifatnya cross - functional.

Pada prinsipnya, rancangan sistem akuntansi pada era industri mengacu pada pelaporan di tingkat tingkat $p$ dan $\mathrm{p}^{\prime}$, sebagian besar hanya mengakui asset tangible, lebih menekankan aspek produksi, menunggu terjadinyatransaksi atau event tertantu untuk melakukan pengakuan dan terpaku pada struktur organisasi hierarkhis fungsional. Rancangan system akuntansi pada era informasi sebaiknya lebih diarahkan pada informasi yang menunjukkan perubahan dalam sumber daya dan proses, system informasi yang demikian diperlukan para manajer karena mereka bertanggungjawab untuk mentransfer sumber daya melalui proses kegiatan, para manajer wajib mampu merencanakan dan mengendalikan system organisasi secara totalitas, yang mana pengukuran dan pelaporan kegiatan manajerial diarahkan pada tingkat " $\mathrm{w}$ ".

Praktik dalam bisnis yang mengarahkan ke rancangan system yang demikian sudah sering didapatkan, misalnya dalam kontrak pengadaan dan di era informasi di definisikan: Tingkat penolakan material yang dapat ditoleransi pada bulan pertama pengadaan adalah 100 per 10.000 unit, untuk tiga bulan berikutnya 100 per 50.000 unit, dan sejak bulan ke lima sampai akhir tahun 100 per 100.000 unit.

Sumber daya dan kewajiban yang menjadi pusat perhatian dalam merancang system akuntansi di era informasi juga wajib diarahkan pada information based assets, assets demikian misalnya penelitian dan pengembangan, sumber daya insani, data dan kapasitas berinovasi, di saat awal asset ini belum nampak di laporan keuangan perusahaan namun di dalam pengambilan keputusan manajer maupun para investor asset ini sangatlah relevan (terkait).

Sistem akuntansi di era informasi jangan hanya terpaku pada pola pengkodean yang mengikuti struktur organisasi fungsional hierarkhis, namun memungkinkan mengkuti pola organisasi jaringan, dan alat bantu yang dapat digunakan adalah Relational Data Base Management System (RDBMS), secara ideal sistem akuntansi inidiharapkan dapat menjaring data pada saat terjadi real time 
bukan sekedar data historis saja, sehingga praktik manufaktur sekarang sudah tidak mentoleransi sediaan barang dalam proses melalui JIT, CIM dan lain sebagainya.

Pada tingkat strategis, manajer puncak diharapkan dapat mengidentifikasi dan menjustifikasi industrinya di tempat berkompetisi saat ini maupun di masa datang, sehingga sistem akuntansi yang diterapkan di tingkat ini diharapkan mampu menjaring informasi yang menyangkut lingkungan IPOLEKSOSBUDTEK (Ideologi, Politik, Ekonomi, Sosial, Budaya dan Teknologi).

Menurut Michael Porter menyangkut model struktur industri dapat dimanfaatkan sebagai acuan dalam menentukan kebutuhan informasi di tingkat strategis, yang dibagi dalam lima elemen pokok, yaitu; ancaman pendatang baru, ancaman barang substitusi, bargaining power melawan supplier, bargaining power melawan customer dan posisi dalam berkompetisi.

Meskipun tidak semua informasi yang ada dalam ke lima elemen tersebut dapat di jaring dan dipantau namun masih ada yang dapat ditampung dalam sebuah sistem informasi. Untuk itu, sistem akuntansi di era Informasi atau berbasis TIini diharapkan untuk dirancang dapat memenuhi kebutuhan informasi perusahaan yang mencerminkan kondisi strategi dan visi manajemen puncak, serta terpadu atau terintegrasi dengan struktur, gaya maupun tujuan manajemen, sehingga dapat dikelola secara efektif dan terarah pada pembentukan perilaku personel yang menuju pada pemanfaatan teknologi untuk menghasilkan competitiveness (keunggulan berkompetisi).

\section{SISTEM INFORMASI AKUNTANSI MANAJEMEN}

Sistem informasi akuntansi manajemen adalah sistem informasi yang memproses input sehingga menghasilkan output untuk mencapai tujuan khusus manajemen. Proses adalah inti dari sistem informasi akuntansi manajemen. Proses dapat dijelaskan oleh aktivitas seperti pengumpulan, (collecting), pengukuran (measuring), penyimpanan (storing), analisis (analysis), pelaporan (reporting), dan pengelolaan (managing) informasi. Output yang dihasilkan dapat berupa laporan khusus, biaya produksi, biaya pelanggan, anggaran, laporan 
kinerja, bahkan komunikasi personal. Model operasional dari sistem informasi akuntansi manajemen diilustrasikan pada Gambar 1.

Sistem informasi akuntansi manajemen mempunyai tiga tujuan utama, yaitu (1) untuk menyediakan informasi yang digunakan dalam perhitungan biaya jasa, produk dan tujuan lain yang diinginkan manajemen, (2) untuk menyediakan informasi yang digunakan dalam perencanaan, pengendalian, pengevaluasian, dan perbaikan yang berkesinambungan, serta (3) untuk menyediakan informasi yang berguna dalam pengambilan keputusan (Hansen, 2000). Ketiga tujuan ini mengungkapkan bahwa manajer dan pengguna lainnya membutuhkan informasi akuntansi manajemen dan perlu mengetahui bagaimana cara menggunakannya. Informasi akuntansi manajemen dapat membantu manajemen mengidentifikasikan suatu masalah, menyelesaikan masalah, dan mengevaluasi kinerja. Informasi akuntansi manajemen dibutuhkan dan digunakan dalam semua lingkup manajemen, meliputi perencanaan, pengendalian dan pengambilan keputusan. Lebih jauh lagi, kebutuhan akan informasi tidak terbatas pada organisasi manufaktur, tetapi juga mencakup organisasi dagang dan jasa.

\begin{tabular}{|c|c|c|}
\hline Collecting & & Special Reports \\
\hline Measuring & & Product Costs \\
\hline Storing & & Customer Costs \\
\hline Analyzing & & Budget \\
\hline Reporting & & Performance Reports \\
\hline Economics Events & Managing & Personal Communication \\
\hline
\end{tabular}

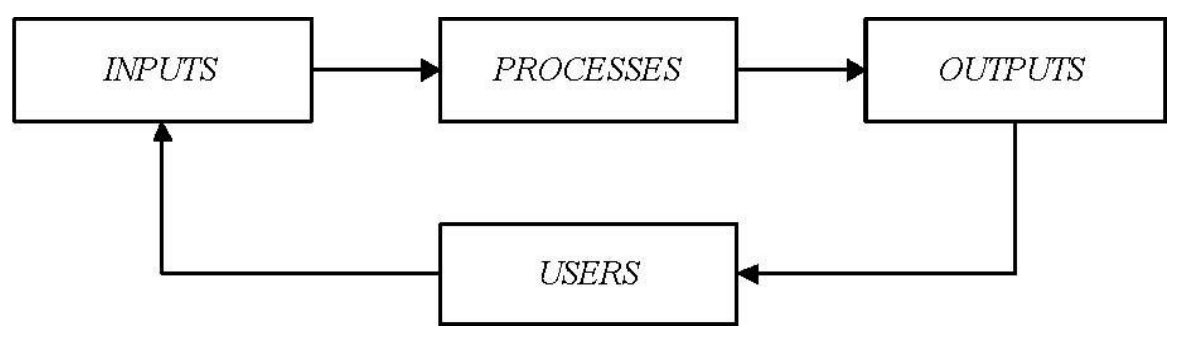

GAMBAR 2. Operational Model: Management Accounting Information System 
Sumber: Hansen (2000:4)

Lingkungan ekonomi yang dihadapi banyak perusahaan dewasa ini telah menuntut adanya pengembangan terhadap praktek-praktek akuntansi manajemen yang inovatif dan relevan. Tekanan persaingan global telah mengubah lingkungan ekonomi. Perubahan ini menyebabkan terciptanya lingkungan baru pada bidang akuntansi manajemen, setidak-tidaknya untuk sejumlah besar organisasi. Karena lingkungan berubah, maka akuntansi manajemen tradisional tidak digunakan lagi. Faktor-faktor kunci perubahan ini adalah (1) orientasi kepada pelanggan, (2) perspektif lintas fungsional, (3) persaingan global), (4) manajemen mutu total (TQM), (5) waktu sebagai unsur kompetitif, (6) kemajuan dalam teknologi informasi, (7)kemajuan lingkungan manufaktur, (8) pertumbuhan dan deregulasi dalam industri jasa, dan (9) manajemen berdasarkan aktivitas (ABM).

Ada dua kemajuan yang signifikan berhubungan dengan teknologi informasi. Pertama, erat kaitannya dengan manufaktur yang terintegrasi dengan komputer (Computer-Integrated Manufacturing, CIM). Dengan proses produksi ter-otomatisasi, komputer digunakan untuk memonitor dan mengendalikan berbagai operasi. Pemanfaatan komputer di dalam seluruh tahap pembuatan produk, mulai dari tahap desain, proses produksi, sampai dengan distribusi, mengubah secara mendasar proses pembuatan produk, dan sistem informasi yang digunakan manajemen di dalam mengelola pabrik

Dengan penggunaan komputer, sejumlah besar informasi yang berguna dapat dikumpulkan dan dilaporkan kepada manajer dengan segera. Apa yang sedang terjadi di bagian produksi dapat diketahui dengan segera pula. Sekarang sudah dimungkinkan untuk memantau produk secara terus menerus ketika mereka bergerak menuju pabrik dan mencatat berbagai hal pada saat yang sama, seperti biaya unit yang diproduksi, bahan yang digunakan, sisa, dan biaya produksi. Hasilnya adalah suatu sistem informasi yang secara terpadu mengintegrasikan data proses produksi dengan pemasaran dan akuntansi.

Otomatisasi tersebut dapat meningkatkan kuantitas dan kecepatan informasi. Karena manajer memanfaatkan nilai sistem informasi yang lebih 
kompleks, maka mereka harus memiliki akses data dari sistem dan mampu memilah serta menganalisisnya secara cepat dan efisien. Di lain pihak, ini mengimplikasikan bahwa alat-alat untuk analisis harus andal.

Kemajuan kedua adalah ketersediaan alat-alat yang dibutuhkan, seperti ketersediaan komputer personal (PC), software, dan paket-paket grafis yang memudahkan pengguna (user friendly). Komputer personal berfungsi sebagai penghubung komunikasi ke sistem informasi perusahaan, sedangkan software dan paket grafis memberikan manajer kemampuan analitis untuk menggunakan informasi tersebut. Alat bantu PC dan software tersedia bagi manajer dari semua jenis organisasi. PC dan software yang mudah pengoperasiannya memungkinkan manajer melakukan lebih banyak analisis dan mengurangi ketergantungannya pada departemen sistem informasi yang tersentralisasi. Jika sebuah PC juga bertindak sebagai suatu terminal dan dihubungkan ke database organisasi, maka manajer dapat mengakses informasi dengan cepat dan menyiapkan lebih banyak laporannya. Akuntan manajemen sekarang lebih fleksibel merespon kebutuhan manajerial untuk aktivitas kalkulasi biaya produksi yang lebih kompleks. Selain itu, kemampuan perhitungan yang cepat dewasa ini telah memungkinkan penyusunan laporan pada saat dibutuhkan. Banyak perusahaan menemukan bahwa peningkatan daya respon dari sistem informasi akuntansi manajemen kontemporer memungkinkan mereka merealisasikan penghematan biaya secara berarti melalui penghapusan sejumlah besar laporan bulanan internal. Hansen dan Mowen (2000) menyatakan bahwa akuntansi manajemen tidak hanya dipengaruhi oleh lingkungannya, namun akuntansi manajemen itu sendiri dapat mempengaruhi perkembangan dalam organisasi, masyarakat, dan lingkungan lainnya.

Beberapa trend yang berpengaruh pada bidang akuntansi manajemen antara lain adalah increasing requirement, advance informations technology, dan just in time divercity. Perkembangan yang terjadi dalam akuntansi manajemen akibat kemajuan teknologi informasi disebabkan oleh beberapa hal, yaitu customer orientation, total quality management, time as competitive element, advances in the information technology, advances in the manufacturing environment, service industry 
growth dan global competition.

Akuntansi manajemen harus mampu menghadapi tantangan perubahan lingkungan sehingga dapat menghasilkan informasi yang sesuai dengan perubahan teknologi manufaktur, teknologi sistem informasi dan persaingan global. Sistem akuntansi manajemen harus mampu beradaptasi dengan kemajuan teknologi. Selain itu, kemajuan teknologi membawa dampak terhadap perkembangan dunia industri yang menuntut adanya kriteria penilaian kinerja perusahaan untuk mencapai tujuan secara optimal. Kriteria tersebut menyebabkan bidang akuntansi manajemen untuk dapat menyajikan informasi yang dapat dipercaya, relevan, tepat waktu, lengkap, dapat dipahami, dan teruji dalam rangka pengambilan keputusan manajemen, baik strategik maupun taktis.

Kemajuan teknologi informasi juga membawa dampak besar pada perkembangan dalam paradigma maupun pada teknologi manufaktur. Beberapa faktor akuntansi manajemen yang mendasar mengalami perubahan akibat penggunaan teknologi informasi. Perubahan tersebut antara lain mencakup proses perencanaan, pengendalian aktivitas rutin, struktur organisasi dan situasi kerja. Dalam situasi dimana lingkungan berubah, maka rencana organisasi juga harus berubah agar tetap bertahan dan keadaan organisasi tetap stabil. Organisasi yang dihadapkan dengan perubahan lingkungan harus responsif jika tidak ingin mengalami penurunan aktivitas yang tidak dapat dihindarkan. Kondisi ini mengharuskan manajemen untuk selalu melakukan peningkatan yang inovatif secara kontinu disegala aspek agar perusahaan dapat tetap bertahan dalam persaingan yang sangat ketat, bahkan dapat memungkinkan perusahaan dapat menjadi leading company.

Akuntansi manajemen hendaknya memperhatikan aplikasi konsep-konsep manajemen dan akuntansi yang tepat, serta teknik untuk menyajikan informasi keuangan yang berguna bagi manajemen dalam melakukan perencanaan, pengawasan, pengambilan keputusan, dan alokasi sumber daya yang paling ekonomis. Dengan mempertimbangkan kemampuan yang dimiliki, penerapan teknologi informasi merupakan suatu tantangan bagi akuntansi manajemen dalam menghadapi teknologi yang ada. Akuntan manajemenlah yang 
menentukan keputusan untuk menyesuaikan kemampuan teknologi informasi dengan kemampuan atau kapasitas perusahaan. Akuntan manajemen bertanggung jawab menciptakan iklim yang positif untuk melakukan perubahan didalam suatu organisasi. Jelasnya, terdapat keuntungan bagi manajemen untuk mengaplikasikan teknologi informasi. Teknologi informasi juga dapat memberikan kesempatan dan mendukung perusahaan untuk mampu lebih berkompetisi dalam era globalisasi. Pengertian kemampuan yang lebih kompetitif mengacu pada penyediaan fasilitas untuk dapat bersaing melalui perbaikan mutu pelayanan.

Berikut ini adalah beberapa contoh implementasi teknologi informasi dalam akuntansi manajemen. Penerapan EDI dalam Just In Time (JIT) menawarkan pengendalian persediaan, mengarahkan orientasi pada kualitas dan efisiensi tenaga kerja. EDI juga memberikan peluang pada akuntan manajemen dalam meningkatkan kualitas yang berkaitan dengan production, shedulling, sales forecasting, mempercepat internal response time, berhubungan secara lebih dekat dengan pelanggan, dan membantu manajemen dalam meningkatkan pengendalian aktivitas bisnis. Dalam Activity Based Costing (ABC), teknologi informasi dapat diterapkan untuk mengolah informasi biaya sehingga dapat memberi kejelasan mengenai sumber atau penyebab dari pos-pos biaya secara cepat dan terorganisasi. Sedangkan dalam Total Quality Control (TQC), teknologi informasi dapat diterapkan untuk melakukan perbaikan berkelanjutan sehingga memungkinkan menghasilkan produk yang sempurna (zero-defect) dan mutu produk merupakan tanggung jawab dari semua bagian. Perkembangan teknologi informasi dalam akuntansi manajemen juga dapat menyediakan informasi tentang korelasi antara biaya dan waktu dengan cepat dan relevan. Hal ini menjadikan manajer mampu merespon perubahan kondisi pasar secara cepat dan tepat. Selain itu, penerapan manufacturing cell dapat mempercepat waktu yang digunakan untuk produksi dan menurunkan biaya produksi.

Munculnya Computer-Integrated Manufacturing (CIM) juga merupakan salah satu bentuk penerapan teknologi informasi. CIM mengaplikasikan beberapa 
kemampuan. Yang pertama, produk dirancang melalui pemanfaatan sistem rancangan komputer (Computer-Assisted Design (CAD)). Yang kedua, rancangan diuji dengan menggunakan sistem rekayasa komputer (Computer-Assisted Engineering (CAE)). Yang ketiga, produk dibuat dengan menggunakan sistem (Computer-Assisted Manufacture (CAM)). CAM menggunakan mesin dan robot yang dikendalikan oleh komputer. Yang keempat, sistem informasi yang menghubungkan berbagai macam komponen terotomatisasi. Salah satu ciri CAM adalah sistem manufaktur yang fleksibel, yaitu sistem yang mampu membuat produk yang dimulai dan diakhiri dengan menggunakan robot serta alat-alat otomatis yang dikendalikan oleh komputer mainframe. Kemampuan menghasilkan berbagai produk yang sama ini merupakan suatu keunggulan.

Tantangan bagi akuntan manajemen lainnya adalah berupa tekanan luar yang berasal dari partner dagang (internal pressure). Banyak perusahaan dan organisasi yang menyadari bahwa mereka tidak dapat melanjutkan aktivitas usahanya bila tidak bergabung dengan Information Technology Network. Perusahaan yang ketinggalan dalam menerapkan teknologi informasi akan sulit berkomunikasi dengan yang lain disamping tidak dapat bersaing. Sedangkan perusahaan yang telah mengimplementasikan teknologi informasi merasa enggan untuk berhubungan dengan perusahaan yang belum mengimplementasikan teknologi informasi.

Akuntan manajemen juga harus mempertimbangkan pesatnya perkembangan teknologi informasi. Mereka harus mampu menyesuaikan tingkat perkembangan perusahaan dengan tersedianya perangkat keras dan perangkat lunak yang ada. Implementasi teknologi informasi harus mempertimbangkan bukan hanya biaya investasi saja, melainkan juga biaya perawatan dan biaya operasi, termasuk biaya tenaga ahli dan pemakaian jaringan pada pihak ketiga.

Akhirnya, dalam mengadopsi dan mengimplementasikan teknologi informasi harus juga disesuaikan dengan kultur atau budaya manusia secara umum. Jangan sampai dalam mengadopsi dan mengimplementasikan teknologi informasi tersebut hanya melihat dari sisi teknologinya saja tanpa mempertimbangkan konteks sosial dan kultur di negara asal yang kondisinya 
jauh berbeda. Dari gambaran diatas, terdapat suatu fenomena yang menarik, yaitu sistem informasi dan teknologi yang canggih akan memberikan peluang untuk membuat organisasi lebih hidup.

\section{BERBAGAI MASALAH YANG TIMBUL AKIBAT IMPLEMENTASI DAN PERKEMBANGAN TEKNOLOGI INFORMASI DAN CARA MENGATASINYA}

Perkembangan teknologi informasi disatu sisi menguntungkan akuntansi manajemen. Tetapi disisi lain dapat menimbulkan beberapa masalah. Bahkan teknologi informasi merupakan salah satu penyebab adanya tekanan bisnis pada organisasi. Untuk mengatasi berbagai masalah yang timbul akibat perkembangan teknologi informasi, maka diusahakan beberapa tindakan. Masalah resistance to change harus dihilangkan karena hal ini dapat mengakibatkan menurunnya produktivitas, meningkatkan angka absensi, dan mengurangi motivasi atau pemogokan kerja (Gordon, 1993). Untuk mencegah kondisi yang tidak diinginkan, Gordon menyarankan agar anggota organisasi atau pekerja dilibatkan dalam pelaksanaan tugas tertentu dan menciptakan lingkungan yang mendukung kualitas anggota organisasi. Selain itu perlu memberikan kesadaran pada karyawan bahwa penggunaan teknologi informasi dapat memberikan manfaat dalam jangka panjang dan menunjukkan kelemahan sistem lama. Selanjutnya Gordon mengajukan beberapa hal yang harus dilakukan untuk mengurangi resistance to change terhadap perubahan implementasi teknologi informasi, antara lain communication, educational program, evolusional change, employee involment, new policies and procedures, staff change, temporary structure dan steering committee.

Untuk dapat memiliki keahlian dan kemampuan tentang teknologi informasi, maka anggota organisasi perlu mendapatkan tambahan pendidikan dan pelatihan serta pemberian ketrampilan-ketrampilan yang relevan.

Selain itu, sebelum pihak manajemen organisasi mengimplementasikan teknologi informasi yang baru, mereka harus mempertimbangkan besarnya biaya yang diperlukan dan manfaat yang akan diperoleh (cost - benefit analysis). Teknologi informasi akan diterapkan apabila manfaat yang diperoleh dengan 
menggunakan teknologi informasi lebih besar daripada biaya yang dikeluarkan untuk mengimplementasikan teknologi informasi. Hal ini disebut juga sebagai value of information technology. Oleh karena itu, akuntan manajemen perlu mempertimbangkannya dengan baik sebelum mengambil keputusan. Keamanan harus senantiasa ditingkatkan, untuk menghindari penyalahgunaan teknologi informasi. Misalnya dengan menyimpan komputer pada tempat yang aman, hanya boleh digunakan oleh orang-orang tertentu yang berkepentingan, penggunaan password, dan pembuatan access control matrix.

\section{KESIMPULAN}

Untuk mempertahankan kelangsungan hidup suatu organisasi, harus disadari bahwa lingkungan usaha akan selalu berubah, termasuk teknologi informasi yang juga mengalami perkembangan. Dengan berkembangnya teknologi informasi mengakibatkan perubahan-perubahan dalam bidang akuntansi manajemen. Akuntansi manajemen akan menyesuaikan dengan perkembangan kegiatan perusahaan.

Kehadiran teknologi informasi memberikan banyak manfaat bagi perusahaan, seperti mampu meringankan aktivitas bisnis yang kompleks serta menghasilkan informasi yang dapat dipercaya, relevan, tepat waktu, lengkap, dapat dipahami, dan teruji dalam rangka perencanaan, pengendalian dan pengambilan keputusan manajemen. Selain itu efisiensi operasi perusahaan dan kinerja perusahaan juga dapat ditingkatkan. Akibatnya perusahaan dapat tetap bertahan dalam era informasi serta mampu menghadapi persaingan pasar global.

Selain menghasilkan manfaat, perkembangan teknologi informasi juga dapat menimbulkan beberapa dampak negatif bagi perusahaan, seperti tertutupnya kesempatan kerja, timbulnya resistance to change serta timbulnya kejahatankejahatan teknologi informasi yang dapat merugikan perusahaan. 


\section{DAFTAR PUSTAKA}

Bodnar, George H. and William S. Hopwood, (1998). Accounting Information System. $7^{\text {th }}$ edition. Upper Saddle River-New Jersey: Prentice-Hall International, Inc.

Elliot, Robbet K. (June 1992). "The Third Wave Break on the Shore of Accounting". Accounting Horizon, vol. VI/2, page: 61.

Fazio, Regina (March-April 1994). “The Right Way to go Global:an Interview with Whirpool CEO, Davit Whitman". Harvard Business Review, page:135-145.

Gani Venus. 1999. "Perluasan Peranan SIA pada Pelaporan Keuangan di Era Teknologi Informasi". Media Akuntansi. No.34/Th.VI/ April 1999.

Gordon, Judit R. (1993). Organizational Behavior. $4^{\text {th }}$ edition. Needham Height-Mampu: Allyn and Bacon.

Hall, James A. 2001. Accounting Information Systems. 3th edition. Cincinnati: Shout- Western College Publishing.

Hanscombe, Richard and Philiph Norman (1989). Strategic Leadership: The Missing Link. International edition, Singapore: Mc Grawhill Book Co.

Hansen, Don R. and Maryanne M. Mowen (2000). Managemen Accounting. $5^{\text {th }}$ edition. CincinnatiOhio: South-Western College Publishing.

Hansens, JV. And NC. Hill (December 1989). "Control and Audit of Electronic Data Interchange". MIS Quarterly. page: 402-403.

Maharsi, Sri. 2001. Pengaruh Perkembangan Teknologi Informasi di Bidang Akuntansi Manajemen. Surabaya: Universitas Kristen Petra.

Mulyadi, (1993) Akuntansi Manajemen: Konsep, Manfaat, dan Rekayasa, Yogyakarta: Bagian Penerbitan Sekolah Tinggi Ilmu Ekonomi YKPN.

Noviera, Naniek. 2000. Pengaruh Kemajuan Teknologi Informasi Terhadap Perkembangan Akuntansi.

Romney, Marshall B. and Paul John Steinbart (2000). Accounting Information System. $8^{\text {th }}$ edition. Upper Saddle River-New Jersey: Prentice-Hall International, Inc.

Simamora, Henry (1999). Akuntansi Manajemen. Jakarta: Salemba Empat.

Supriyono, R.A. (1997) Akuntansi Biaya dan Akuntansi Manajemen untuk Teknologi Maju dan Globalisasi, Yogyakarta: BPFE Universitas Gajah Mada,.

Taufiq, Muhammad (2002). Dampak Perkembangan Teknologi Informasi Dalam Profesi Akuntan Dan Implikasinya Dalam Dunia Pendidikan. Yogyakarta: STMIK AMIKOM. 


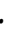

